\title{
CAUSES, FORMS AND EFFECTS OF SOCIAL AND MORAL CONFUSION OF THE INSTITUTIONAL ROMAN-CATHOLIC CHURCH IN POLAND
}

ABSTRACT. Józef Baniak, Causes, forms and effects of social and moral confusion of the institutional Roman-Catholic Church in Poland, edited by Z. Drozdowicz and S. Sztajer, "Człowiek i Społeczeństwo" vol. XLI, Poznań 2016, pp. 49-69, Adam Mickiewicz University Press. ISSN 0239-3271.

The lostness of an individual or institution is manifested in their aversion towards conforming or adapting to the social and cultural conditions in which they are to function or carry out their fundamental tasks. Lostness affects secular institutions as well as religious institutions, including churches. In this paper I demonstrate the lostness of the institutional Roman Catholic Church in Poland over the past 25 years through the reflections of clergymen and theologians, as well as on the basis of sociological research findings. Theologians claim that this lostness also signifies the specific pastoral situation of the Church brought about by the systemic transformations in Poland over this period, previously unencountered by and unknown to the Church, hindering the Church's functioning and inducing it to take erroneous decisions. Lostness takes on a variety of forms and is manifested in numerous spheres of the Church's secular activities, but does not affect its essence or religious identity. However, it does embrace its functions and actions, its attitudes and its decisions, in the area of secular and political activity, its relations with society, and also in relations within the clerical community. Wording it differently, lostness applies to the human structure of the Church, and within this above all the bishops and leaders who guide it and manage its assets, and who also perform an instructional and educational function towards the Church's faithful.

Józef Baniak, Adam Mickiewicz University in Poznań, Institute of Sociology, ul. Szamarzewskiego 89ab, 60-568 Poznań, Poland, e-mail: j.baniak@amu.edu.pl

\section{Introduction}

What does "being at a loss" mean - what constitutes its essence, in what ways does it find expression, what causes it and what role does the phenomenon play in human relations - individual, collective and social? What are the 
sources of the Roman-Catholic Church in Poland being at a loss, what signs are there of this state - what are its causes, forms, symptoms and consequences for the functioning of the Church as an institution as well as a community of religious people, as well as for the relations between the Church and society and its members? The present paper aims at answering these questions; it is made possible based on the existing statements of authoritative Church figures, combined with the results of scientific research into the Church and its difficulties with fulfilling its social and religious mission, as well as with its accommodation to the conditions of social and cultural life.

Being at a loss constitutes a relatively complex phenomenon, conditioned by multiple factors, and therefore is not an easy phenomenon to define. Linguistically, it bears a strict association with the notion of "loss," or of "losing" something precious or someone important for oneself, or for one's own relations, bonds, contacts, actions or plans of some existential or emotional significance. Being at a loss also broadly entails haplessness, incapacity or unwillingness to adjust or adapt to given conditions of existence and functioning, which are external to the capacities and expectations of the individual or institution expressing such a hapless attitude or behaviour. Being at a loss relates to the human person as an individual as well as to the people constituting an organisation or institution - the consciousness, activity, thought, conduct and actions inconsistent with the expectations of those to whom they are addressed and transmitted. Being at a loss can also mean a retardation (through animosity or ill will) or a disruption of human relations - both individual and social, visible in institutions and organisations. At its foundations, being at a loss may result from a variety of external reasons and causes, as well as from the internal conditions of the individual, institution or organisation - it may also express itself in a variety of forms. In effect, it is capable of causing results negatively affecting relations and relationships between humans as individuals embedded in different social constellations. Being at a loss affects both those who are lay persons and the clergy, both the lay institutions and the ecclesiastic institutions; however, it may assume different forms, expressions and consequences. The focus of the present paper is on the way in which the institutional Roman-Catholic Church seems to have been at a loss for a number of years, which has an important impact both for the Church and for the society within which the Church serves its religious mission and undertakes secular endeavours.

The Roman-Catholic Church in Poland, as a local branch of the universal Church, has almost always been going through various disturbances and dilemmas - religious-doctrinal, moral and secular. Difficult challenges have 
affected the Church in almost every period of its long history, yet, the great scope and high degree of complexity of those traumatic experiences was especially visible in the $20^{\text {th }}$ century. In difficult situations and circumstances, the Church would exhibit being at a loss when it came to its relations with society and its own followers; it expressed fears and anxieties and its own haplessness and ineptitude at fashioning its religious and social doctrine to the conditions of the times and expectations of the people, i.e., of its own members. On the other hand, however, the Church continuously strove to maintain in the Polish consciousness the high regard for its religious and moral authority, as well as to fortify the conviction that it remains indispensable for the nation, state and family - which has led to social resistance. Under such circumstances, the Polish people observed, and researchers attested, that the Church and clergy would be at a loss on several levels when faced with unfamiliar conditions of its functioning, and the Church would strive to get out of this impasse and attempt to re-establish social contact.

There are multiple reasons for the Church being at a loss, and sometimes they are initiated by ecclesiastic powers of different managerial ranks bishops or parish priests. These reasons have been of both the religious and the moral variety, such as for instance in the case of the attempt to force society to follow one single religious doctrine, marriage and family ethos, set of sexual customs, or to accept the promotion of the Church religious and secular doctrine visible for instance in the arbitrary introduction of religious classes to secular schools and the constant talk of the supposed necessity of Catholic religion in the process of rearing the youth. This also relates to the secular profile, noticeable in the dynamic and wide-scope intervention of the Church hierarchy in the politics of the state and of the local government - influencing legislation, or demanding that the state returns Church property lost often in historically far away times.

For the Polish Roman-Catholic Church, being at a loss has come in a variety of different forms, and each of them resulted in different negative effects or consequences for the relations with the state and society. Examples of such consequences came in the harsh criticism of the Church and its secular and political engagements, the negative evaluation of the immoral behaviour and actions of the parish priests - especially in cases of paedophilia and other sexual excesses; the criticism levelled at monasteries due to their material covetousness; the indifference on the part of many Catholics with respect to the religious and moral doctrine of the Church, or the disappearance of the bonds of the school and academic youth with the Church, its religious and social organisations, as well as with the parish clergy. 
The present position of the Roman-Catholic Church, and the attitudes of the Polish people towards it, seem different than 25 years ago - and even then, those relations were far from perfect, and demonstrated that the Church was bewildered by its place in society; yet, the scope and intensity of this being at a loss have definitely become greater. Sociological research demonstrates the dynamics of this growth, as well as shows the unwillingness on the part of Church authorities to change their attitudes towards society and its real problems, or to change the language of the Church in a way that would make it more comprehensible and empathic, while decreasing its aggressive and authoritarian features (cf. Baniak 2015; Borowik 2005, pp. 149-166). Nevertheless, this being at a loss is not something new or atypical for the Church, which sticks to its course and degrades its relations with the people. Researchers, including theologians, have observed these symptoms much earlier and they have attempted to sensitise the Church authorities to the necessity of assuming a more positive stance in social relations, and in the methods of parish and special ecclesiastics. The Church failed to utilise those remarks and suggestions, and it still keeps its own positioning as a dominant and authoritarian entity, vis-à-vis society and the faithful - thus, it demonstrates the scope of its power and wearisome defence of its interests, and demands total obedience and acceptance of its ideas and aims in the religious as well as secular domains. Such an approach and attitude towards society, attempting to enforce its own will, pushes people away from the Church and alienates it from the people who value their own freedom and independence, including in matters of morality, of religion (not to mention the secular issues); it remains far from neutral for the identity of the Church as a socio-religious institution (cf. Przybecki, 1986; 2009, pp. 77-85).

This paper is going to investigate the "history" of the Polish Catholic Church being at a loss, including its various forms and expressions, as well as the principal causes, reasons and negative consequences visible in the Church's relations to society and its own environment. Exposing the multifaceted nature of this phenomenon comprises the aim of this endeavour, and the statements quoted - especially those of Fr. Roman Rogowski - as well as the research data, constitute the sources which I shall utilise in this work. It was necessary to use the method of content analysis of received materials and of empirical research in taking up this topic. My research hypothesis has been that the Church's being at a loss has increased in spite of the social possibilities that existed which made it easier and in fact suggested changing course in order to mend relations with society. The reader of this paper will be able to see the accuracy of this hypothesis, or perhaps to find it wholly or partially inaccurate. 


\section{Analysis of the perceived problem of the Polish Church being at a loss}

The situation of the Roman-Catholic Church in Poland being at a loss has been accurately depicted by Prof. Fr. Roman Rogowski in 2001: “[...] The Church on the banks of the Oder and the Vistula lives on its faith and has local experiences. Communism was one of them, as it attempted, on the one hand to push the Church to the margins of social life, while constituting, on the other hand, an opportunity for mobilisation in order to keep going and work within the nation. Those actions have been focused on the ceremonies and on administration, on tradition and all that came in the form of the 'government over souls.' This pushed other issues to secondary importance, as in the case of moral attitudes, deep preaching, theology and intra-Church public opinion, and this also to some extent concerned the implementation of the decisions of the Second Vatican Council [...] It was with such problems that the Church entered the period of state transformation, and found itself in a new social, political as well as economic situation, and it faced new challenges. Democracy, free market, liberalism, globalisation and European Union - these phenomena were new on the banks of the Vistula and the Oder, and the local Church had to come up with a proper standpoint with respect to them. This was accompanied by new social phenomena such as unemployment and impoverishment of some social strata, privatisation and consumptionism, materialism and the cult of money, as well as moral relativism and religious indifference, religious sects and the influx of foreign cultures as well as the drive to unification in the field of religion, and finally, a lack of clarity in the sphere of values, evaluations and attitudes" (Rogowski, 2001, pp. 89-90). The author claimed, then, that the Church in Poland has come under the pressure of multiple factors "in the pastoral situation, which - with some degree of simplification - could be called being at a loss, this being at a loss obviously does not touch upon the essence of the Church, its identity, but concerns its functions and actions, attitudes and decisions. It relates therefore to the human structure, and especially the hierarchy as well as the episcopate, which directs the Church and constitutes its guiding institution [...] This is a serious condition, which calls for a critical evaluation as well as for seeking means of improvement” (Rogowski, 2001, p. 91).

Unfortunately, these important words and poignant remarks of a prominent Polish theologian have remained prescient throughout the last decades, and have lost none of their prescience in the present times; they remain important both in terms of their content and its message, as the Polish 
Church keeps being at a loss, and gives testimony to this fact in many different spheres of its religious and secular activity. What is more, digging itself deeper into this bewilderment, it loses orientation with respect to the accuracy and righteousness of its decisions, of the shape of its relations with the state, with lay Catholics and many other social environments. It proves incapable of disentangling itself from this state, or perhaps it is unwilling to do so; nonetheless, it cannot regain its former social authority and regenerate the societal needs for its services. The research shows clearly that the constant political intermingling with local and state power, as well as financial business associations, make this state of being at a loss even more acute in the Church and among the clergy, as it moves them away from important duties and the problems of real people. The people do not want to participate in a politically bifurcated Church, which also includes many immorally acting priests; people do not want to hear their ethical and religious admonishments, let alone political directions, which cause moral disgust and make people move away from religion. Polish people demand a de-politicisation of the Church - of its language and modes of action in the country and in the parishes; they also expect the Church to go back to its religious roots of religious presence in society. They want an "ecclesiastic," not a "political" Church, as the bifurcation of its character deepens the feeling of being at a loss - socially, religiously, and morally. The people see this, and they rebel, but they also demand radical changes in the functioning of the Church and in its attitude with respect to the everyday problems of the people. In their view, such changes could "heal" the Church from the state of being structurally and functionally lost (Baniak, 2005, pp. 107-154).

\section{Symptoms of the Polish Institutional Church being at a loss}

Fr. Roman Rogowski observed the fact that the Polish institutional Church had lost its way, and that this related to its central as well as local authorities, almost all spheres of religious and social activity, moral doctrine, and the relations with the state and the social environment. Let us focus on the most important symptoms of this being at a loss, which are visible even in the present-day Church, even if some actions on the part of the Church indicate a regaining of the feeling of strength and power, allowing for the domination over the weak state, and influencing vital national and local affairs. The author writes: “[...] the Church's being at a loss comes in different forms and is reflected in various relations - towards the world and the state, towards man and other Churches and religions, and finally, towards the 
intra-Church situation. One of the main forms of this confusion comes in the form of neglect [...] In the Polish Church it is amplified [...] and those at a loss are Christians constituting the Church upon the Vistula and the Oder" (Rogowski, 2001, p. 91).

\section{Preference for distinctiveness and otherness as a form of the Polish Church's being at a loss}

Institutionally Churches have almost always positioned themselves in opposition to the world - with their ideological posture and their system of preferred values, and wanted to be different than the world ("Ecclesia alia"). This situation has also remained visible in the Polish Church, which variously demonstrates its distinctiveness and otherness in the sphere of its own ideological assumptions, aims, value systems, and the way of exerting religious and secular power in society. On the other hand, this Church is increasingly pushing for the blurring of the boundaries separating it from the secular state on the basis of the Constitution, by way of using the argument that the citizens and the faithful are the same people, and the boundaries between Church and state are arbitrary and artificial, and it would be better for them not to exist. Such an interpretation of this boundary facilitates a foundation for a mass sacralisation of public and state life, and allows the Church to exert real influence (often by diktat) over the decisions of state powers at various levels. Sociological research demonstrates that this duality of ecclesiastic attitudes and actions is hard to comprehend for those secular Catholics who find themselves confused by the Church's secular socio-political strategy; some of them keep asking what the Church hopes to win by way of this incomprehensible course of action, and demand a full separation of those institutions as well as a good maintenance of boundaries and differences separating Church and state (Piwowarski, 1991; Mariański, 2005, pp. 159-202; Baniak, 2010a; 2015).

\section{Artificial structural divisions as a reason for the Polish Church being at a loss}

Fr. Roman Rogowski further points out "[...] Under such circumstances the role of the Church is both responsible and objectively difficult, and it seems that it is somewhat at a loss when it comes to all that happens and comes from the world. The division of the Church in Poland conceived by Jarosław Gowin (Gowin, 1995, pp. 219-230) into traditionalist Catholicism, contem- 
porary Catholicism, the closed and the open, as well as integral Catholicism, may seem a little simplistic and controversial; however, it may point to the Church being at a loss. This confusion is best seen on two plains - European integration and globalisation" (Rogowski, 2001, pp. 92-93). At a somewhat later period, the author adds, the Church was "regrouped" into two mutually hostile camps fighting each other over the capacity to influence the "secular masses," and this division came about due to the actions of both the clergy and the secular Catholics. On the one hand, there was the "Church of Toruń," directed by Father Rydzyk and some bishops, and on the other, the "Church of Łagiewniki," under the patronage of Cardinal Stanisław Dziwisz. Naturally, this division has never been officially proclaimed, and to the contrary, the ecclesiastic authorities and the secular one's associated with the Church denied its existence; yet, the "Church masses" know better, claiming that such a division of the Polish Church is an indisputable fact (Baniak, 2012, pp. 7-20). This division set Polish Catholics at loggerheads, dividing them into two extreme camps: the fundamentalist defenders of the cross, and heart-felt opponents of the presence of the cross in the typically secular space of the Polish state; at the same time this demonstrated to the world that contemporary Polish people want to lead their everyday lives in a secular state, free from aggressive Church influence, while at the same time remaining attached to the religious symbols in their lives, but demanding for them to be placed in a sacred space of the temple. The instigators of this division of the Church have also failed to predict that the Church authorities would call this cross a mere piece of furniture and will call their attitude towards religious dislocation incomplete; they have also ignored the degree to which such divisions deepen the confusion of the Church and move it even further away from society, losing its authentically religious character. Thus, thinking in secular terms, this kind of attitude is curious and actually proves the level of confusion of the Polish Catholic hierarchy, as well as of the lay Catholic activists cooperating with the structures of the Church, which are present at various levels of national and local government.

Fr. Roman Rogowski does also provide an interesting diagnosis of European religiosity, and against this background also of the religious life of Polish Catholics, explaining persuasively that: "European religiosity [...] has never been truly Christian and the rule ‘cuius regio, eius religio' produced in practice people who were superficially sprinkled with holy water while remaining pagan at heart. It was easier to build a magnificent Church, or to put a troublesome wife in a nunnery, than to convert and start living in accordance with the gospels. Therefore, all that is happening nowadays only 
proves that the holy water dried up. With respect to this situation, the Polish Church, specifically its hierarchy, remains divided: some see an opportunity, where others see a threat [...] This remains associated with the question of the responsibility of the local for the universal Church. Specifically, this relates to the missionary work and Polish missionary priests. There are dioceses in Poland with a relative over-abundance of clergy, which not only fail to feel responsible for any missionary work but are even reluctant to provide clergy for the service of the universal Church. This lack of openness for the needs and pains of the worldly Church may serve as a proof of an anaemia of responsibility for God's People and demonstrates a certain type of confusion at the turn of the century” (Rogowski, 2001, pp. 93-94).

Sociological research demonstrates that the fraction of the diocese and monastic clergy working continuously in missionary countries that do not have clerical cadres of their own is not particularly high relative to the continuously high population of the clergy working domestically in parishes and monastic communities. Some monastic associations provide an exception to this rule, and specialise in preparing priests and monks for work in missionary countries, but even in these institutions not all the members have engaged in evangelising missions (Baniak, 2012). This situation is presently visible as there is an over-supply of priests in Poland (over 30 thousand), although the number of alumni has been systematically decreasing in dioceses and monasteries. However, there is no crisis of cadres on the horizon of the Polish Church for many years to come (Baniak, 1997, pp. 97-106; 2010, pp. 307-315; 2012). This does not mean that the Polish ecclesiastic powers would be more ready to share their human resources with other Churches, for whom the cadre shortages hamper their ability to provide religious services. And when it comes to the true nature of the Christianity of the Polish Catholics, who have all been sprinkled with holy water on many occasions, this question remains open. Still, sociological research has uncovered a new phenomenon - non-believing Catholics, who may comply with certain rites for a variety of reasons, most frequently due to customs or family traditions, while being confused in matters of religion, their world-view and morality (Baniak, 2007, pp. 23-43).

\section{Financial greed and desire for enrichment as a reason for the Polish Church being at a loss}

Fr. Roman Rogowski, citing the opinion of John Leskovitz (por. Leskovitz 2013), puts forward a bold claim that the Church still maintains an ambiv- 
alent attitude towards capitalism and the means created by the scale of its capacities. The Church proves not nearly radical enough in stating the scale of abuse within this system, of dynamically developing economic cronyism as well as the relations between political power and business; it is far too lenient in its treatment of the rich and of practical materialism, as in view of their offerings and gifts it does not want to run the risk of offending them. Sociological research analysing the scale of corruption globally as well as in Poland does also point to the conclusion that this phenomenon is present in the Church - in its various structures and institutions (cf. Baniak, 2012a, pp. 167-190). Rogowski contends that this problem is also present in Poland, as the ecclesiastic powers keep looking for support on the part of the wealthy, want to maintain influence on central and local government, and are especially emphatic upon the restitution from the state and society of Church and monastic property lost in sometimes the very distant historical past. The properties over which they regain control are often quickly monetised, and when it comes to those that cannot be given back - hundreds of millions of zlotys are paid in reimbursements, which are often fought over aggressively and in a way that contradicts the ethos of the Church; all this apart from the regular state subsidies for almost all forms of Church religious activities. In these endeavours, the Church has lost its way, according to the author, by demonstrating a limitless greed for financial gain and an unstoppable drive to riches, while at the same time preaching all forms of poverty and "disregard for the affairs of this world while focusing on the heavenly affairs” (Rogowski, 2001, p. 93).

Both lay Catholics and other Polish people can readily see this duplicity and moral confusion of the stance of the Church and the clergy, especially if they are not well-off or are indeed touched by poverty and social exclusion, and they hold the Church responsible for an overreaching desire for enrichment and "gaming" the state. Sociologists see a kind of "disgust" of this desire of the Church to get richer at all costs. Respondents frequently claim that the Roman-Catholic Church is the most affluent institution in the country, and that the parish and monastic clergy counts among the social groups positioned highest on the scale of affluence, while the social masses are continuously pauperised (cf. Kutyło, 2012, pp. 149-166; Kwiatkowski, 2001, pp. 107-120).

\section{Bishops' desire for power as a reason for the Polish Church being at a loss}

Father R. Rogowski states that "from the theological point of view, the Church should stand in moral opposition to the authorities and governments. 
This should be strictly moral opposition, but should be declared against any forms of power [...] However, the Church in Poland is clearly at a loss, as if its attitude was supposed to confirm the pronouncement of the prophet Daniel: 'today we have no right to open our mouths' $(3,33)$. At the same time, among the Polish bishops one can encounter the opinion that 'the Church would not be a gendarme in Poland'; this is, on the one hand a convenient attitude, while on the other hand it constitutes a misunderstanding of what the Church is supposed to be for this world, especially that in some countries the conscience of the nation seems to be constituted by the mass media, while the Church remains silent. Public opinion in the country holds that the episcopate uncritically opposes the authorities, argues for patience and obedience, and any social protests, especially those of the more radical sort, are held to be bad and detrimental. The press is more cautious writing about the 'pro-government Church' and holds it against the Church that it remains indifferent with respect to the situation endured by the great mass of society. One should objectively admit, however, that in this respect the Polish episcopate is divided, although unevenly, yet, a serious part of it assumes a different attitude” (Rogowski, 2001, pp. 95-96).

This formulation by Fr. Rogowski seems somewhat too lenient nowadays, as the "power desires" of the Church and the Polish hierarchy are overly huge and growing - they do not want to leave any sphere of social life free of their efforts to influence and moralise society; however, three spheres seem to attract their utmost attention in the view of the Polish respondents: an over-reaching desire for power and the will to govern the consciences and the will of the people; an unbounded desire for power and for a convenient life-style ("heaven on Earth"); a spoiling of sexual pleasure ("clericalism of the secular"), including in the marital and family life ("restricted sex"). The Church, being ideologically at a loss, is unwilling to comprehend that the contemporary society - its members - for the most part tend not to accept the ethical norms of ancient provenance, and are willing to emigrate from the Church without breaking their bonds with God. People asked about the divine source of the moral rules propagated by the Catholic Church, frequently answer that God "has nothing to do with them," and that "these norms have always been devised by the Church and clergy in order to control human consciences," and that "priests are living in enforced celibacy and want to impose their lifestyle on everyone else," and that "people who rely on their own decency and conscience know best for themselves what is good for them and what they should not do in order to be in agreement with God and other people," and that "it is high time for people to decide about 
their own morality rather than follow the moralising of priests, whose ideas about life are hazy” (Mariański, 1990; 2013, pp. 147-198; Baniak, 2015a, pp. 51-91). These remarks by Rogowski can be supplemented by the caution of Jeana Nublier who unmasks the hypocrisy of the clergy and their duplicitous attitude towards the poor: "[...] Those living in palaces and sitting at the side of those in power, cannot easily empathise with the situation of the homeless and the deplored, and cannot easily consider themselves shepherds" (Nublier, 1989, p. 67), as well as the opinion about the Church expressed by bishop Helder Camary that the Church should engage and show solidarity only with the people, and if the government also shows engagement in the interest of the people, then it can meet in those actions with the Church; however, when one keeps driving only fast cars, it remains difficult to touch poverty (Camara, 1995, pp. 124, 157). Fr. Roman Rogowski adds in this context that "[...] in the local Polish Church there are no clear attitudes with respect to these phenomena, and this is the reason why the national press writes about 'the higher clergy having irresponsibly broken away from social sentiments' It seems that this confusion is strongest when it comes to the care of the family [...] This concerns not merely the Church's charitable actions, which are truly great, but systematic actions, which could alleviate the fate of the poor and of the families” (Rogowski, 2001, pp. 97-98).

\section{The Polish Church being at a loss in the context of its relationship to the world}

Fr. Roman Rogowski, being a deep-thinking contemporary theologian having a firm understanding of the problems of Church life, states another accurate diagnosis concerning the Polish Church and the problem of it being at a loss: "in the Church, in its human structure, there comes to the fore two apparent fronts, one wants the Church to become more like the world, while the others wants for the world to become more like the Church becoming divine. These two tendencies are also visible in the Polish local Church, while it is also infused with the conviction - especially strong in some circles - that the situation everywhere around the world is worse, while the Polish Church does well and perhaps even very well [...] especially if one observes the world from the point of view of the car of the bishop visiting a parish. Philosophers of history call the $19^{\text {th }}$ century one of madness, while the $20^{\text {th }}$ seems one of narcissism, but as the course of time in the Church runs slower, it is the former century that continues within the Church. In the Polish Church, it finds its expression not only in the aforementioned 
conviction, but also in a peculiar "cult of personality" which gave rise to the Polish mania of monuments that demonstrates the dearth of conviction in the revealed rule that: 'do not put your servant on trial, for no one living can be found guiltless at your tribunal' (Ps 143,2). Well, no one knows how many are "the actual number of monuments to Jean Paul II, which still failed to enrich the religiosity and morality of the Polish people."

\section{Triumphalism and materialism of the Polish Church as a form of it being at a loss}

Enumerating further the forms of being at a loss, Fr. Roman Rogowski states another charge against the Polish local Church: "[...] Another form of the local Church being at a loss comes in the form of its triumphalism, overgrowth of structures and materialism. 'The theology of littleness is a basic category of Christianity'” - he refers here to the words of Cardinal Joseph Ratzinger (1997, pp. 13, 125). The Church compromises its opinion by sticking to the institutional structures even if there is nothing behind them, and they are only emanations of bureaucracy. Looking at the Church in Poland - continues Fr. Rogowski - one has the impression that Marc Aurelius was right to say that who does not govern starts to build. Indeed, the erection of giant temples almost on the scale of pyramids, while there is a steady decline in the number of people attending Church services, might be disturbing, especially that the financial resources spent on such buildings could be devoted - in the name of the love of the universal Church - to the assistance in the construction of the much needed temples in Russia or Ukraine [...] One could also pose the question whether some of the clerical work in the curia could not be performed by lay people, while the priests working there would be sent preaching, or doing missionary work? The problem of the materialism of the Church, in turn, is as old as the Church itself [...] The confusion of the local Church in this matter can be demonstrated by two examples: firstly, one could point to the non-transparent nature of Church finances, which creates an impression that the Polish Church is very affluent, and that there is a continuous material inequality leading to some Church-men driving Mercedes cars while others can barely afford a bike; secondly, one could point to the unreasonable policy when it comes to the restitution of confiscated Church property [...] the Church should simply have waited for the implementation of the reforms of the healthcare and education systems, so that local governments would have to come asking for taking over those properties [...] The Church fails to recognise the importance of 
informing society and the faithful of its intentions and actions" (Rogowski, 2001, pp. 101-102).

It seems that the caution given to the Church by Fr. Roman Rogowski was overly bold at the time, but also it was rather weak in the predictive sense. The Church powers proved highly adept at tackling the problem of property restitution when it came to those confiscated by the state at various historical moments. This is clearly visible to all the Polish people, who are at the same time expressing their disbelief and disgust at the scale of the practical materialism of the bishops and many parish and monastic priests. The erection of Church buildings is to a large extent subsidised by the state and local governments, who prove obedience with respect to the temporal demands of the Church. The Church has regained its good mood as well as the feeling of power visa-vis the state, and thinks it only proper that this is the way things should be in the country between the Vistula and the Oder, as the conviction is commonplace within Church institutions that it is the clergy that should rule and the secular people are only meant to "contribute donatives and listen to commands," as the power of the clergy comes directly from God. The problem is, however, that this conviction is questioned and rejected by a majority of lay Catholics (approximately 75\%), who contend that it is anachronistic and unwise, and that it is only the clergy that are prone to thinking in such categories. Polish secular Catholics are increasingly bolder in their endeavours to part from Church thinking and acting in such a way as to independently realise their religious needs and pursue God's path without the help of the clergy. In this respect, the Church is definitely at a loss, and has no plan of remedial action, which would allow for it to regain trust and authority in the eyes of the faithful as well as of other members of the increasingly more-secularised society. For the most part, the lay Catholics feel alienated from the Church, they do not feel responsible for its fate and needs, and do not feel bound to the parish community as they no longer constitute it themselves (Sroczyńska, 2002).

\section{The passive pastoral model, the crisis of homiletics and the imposition of school religion classes on the youth as symptoms of the Polish Church being at a loss}

Fr. R. Rogowski exposes this problem in the following fashion: “[...] When it comes to ministry, the symptom of confusion comes in the form of the passive mode of priesthood, which is associated with the difficult problem of teaching religion and the crisis of preaching. In most cases the Polish priesthood acts 
in accordance with the principle of 'serving the needs of the population', and so responds only to those who turn up, who come. There are no missionary activities, and so there are no or perhaps only very few conversions [...] For the Polish Church, it came as a great success that the teaching of religion was introduced to schools, yet, this success came at a steep price: the disregard or discontinuation of the care for spiritual life, for the religious life of young people. It was surmised that the teaching of religion at schools would solve all the problems of religious formation and Christian life. Such convictions turned out to be false, and thus the need arose for parish-based religion-teaching, which would spiritually form young Polish people and bring them up as conscious Christians” (Rogowski, 2001, pp. 103-104).

Unfortunately, sociological research demonstrates that this reasonable proposal on the part of Fr. R. Rogowski has not yet been implemented, and the youth is still forced to learn religion in a secular school - and Church properties, which used to serve the needs of religious study, are nowadays hired to tenets for various uses, often involving services or trade, and sometimes are simply left vacant. In this realm, the confusion of the Polish Church is paramount, and its upper echelons have no rational idea for escaping this impasse, as what only counts is the dominance of the Church over the secular educational system. At school, the students want to receive knowledge about various religions rather than being indoctrinated in the Catholic spirit; they also want reliable and objective methods derived from religious studies. The youth wants to gain knowledge about religions at school, and to get Catholic teaching in the Church, often in combination with philosophy and ethics. Unfortunately, the expectations of Polish youth are unlikely to be satisfied anytime soon, as the Church has no such intentions and does not intend for religious teaching to go back to the parishes and temples. For the Church and the bishops, teaching religion in secular schools constitutes a symptom of (their) power over society, and this power is of far greater importance than the social expectations and demands of the youth (Baniak, 2000, pp. 237-260; Potocki, 2007, pp. 101-162).

\section{Disregard for the needs of lay Catholics as a form of the Polish Church being at a loss}

Being at a loss typically stems from the disregard or disdain for the needs of the people, or from the lack of capacity for solving problems and explaining dilemmas. This situation is upon the Church and relates to its multidimensional confusion. How is the Church supposed to get out of this confusion 
and to regain the authority among its members. This problem is complex and difficult, and it requires a well-thought-through diagnosis and bold decisions combined with the hope for success. Fr. Rogowski envisages the solution to this problem in the following way "[...] Every local Church has its problems and difficulties, and sometimes its own kenosis. This is also true of the Polish Church, and as we all constitute it, therefore we should all follow in the footsteps of David's reflection: 'If the foundations fall to ruin, what can the upright do?' (Ps 11,3). He may achieve a lot, on condition that Hermas describes: 'The Lord shall have pity for you, only do not let yourself be idle'” (Rogowski, 2001, pp. 106).

Well, one would wish that the faith and hope which is expressed by this - secularly speaking - learned theologian-priest were also characteristic of those important figures of authority in the Polish Church who are instrumental to the determination of its current and future fate. One would also wish for the ordinary Church members to partake in them, as they would otherwise find it hard to discover their place and role in the confused Church. Experts on the topic say that every time one is at a loss this involves a complex process which proves difficult to get rid of from an afflicted institution, especially if it has known awareness of the process or has no will to escape from the condition. Such an awareness is lacking in the Polish Church and among its leaders. They are incapable of fostering an authentic dialogue with society as well as with the faithful, and prefer to resort to diktats, which they see as the only way to evangelise people. Unfortunately, however, this method indicates their weakness and confusion (Baniak, 2015).

\section{Disappearance of trust and the decline of authority among society and the faithful as the result of the Polish Church being at a loss}

As a result of its being lost in society and in its socio-political dealings with the state, the institutional Church in Poland loses its authority among its own members as well as various opinion-forming circles, and the people become suspicious of its actions and decisions. Mirosława Grabowska has rightly pointed out that the trust (approval) and distrust (disapproval) with respect to the institutional Church, and especially to the hierarchy, in public life (both at the state and local-government level) are conditioned by a variety of factors, including the contemporary political context, and the inclusion of the Church in some political or legal-moral debate which may change people's attitudes towards this institution. In the evaluation of this author "[...] It is worth remembering the relatively long-term effects 
of such influences - there is nothing strange in their subsiding, as we are becoming ever more distant from the past” (Grabowska, 2001, p. 137). It also seems that Monika Mazurkiewicz is right when she writes: "[...] In the pluralist Polish society the Church cannot aspire to be an authority for all citizens, for the whole society. In spite of the relatively high degree of social trust in the Church, its competencies are located more in the domain of spiritual problems and needs of the people. This is accompanied with the refusal of the Church's right to speak out on specific questions of public life, especially those closely connected with everyday life. The results of research show that the faithful expect the Church to satisfy their religious needs, while keeping away from the spheres of public and private morality" (Mazurkiewicz, 2001, pp. 309).

\section{Inadequate model of the Church and political engagement of the clergy and bishops as a reason for being at a loss socially and morally}

This problem boils down to the fact that Church authorities know the expectations of the faithful in this respect, and yet fail to accept them, attempting to enforce their own Church view of the Church, within which it seems hard to miss the old custom of the hierarchy to combine the "competences of the altar" with the "competences of the throne." They see this fusion, in contradiction to the views of the faithful, as more amenable to the authority of the Church and more conducive to the build-up of its institutional authority. However, the new political and social conditions of democratic Poland require a new form of ecclesiastic and clerical presence in the secular state and society. The necessity of such change had been postulated by Fr. Władysław Piwowarski, who observed the trend of the Church diverting from the proper path of building bonds with society, which depressed the societal trust in the social policy of the Church: "[...] The model of the Church requires rethinking. We were formed within the framework of the popular Church, which can only fully function in a traditional or totalitarian society. [...] The contemporary situation changed everything. Without understanding those changes, some think that the authority of the Church is declining. The new pluralism resulted in the restriction of the role of the Church as one of the sub-systems of society. The Church can now intensify its evangelising mission, strengthen the impact on society through its critical function and seek for solutions to pressing social problems through dialogue with people of different world-views as well as with all social 
forces. It means, however, that while there was a rise in the moral authority of the Church on the social and religious plane, there was a parallel decline on the political plane, which is only right as politics does not come within the purview of ecclesiastic mission" (Piwowarski, 1991, p. 1). Whether one can nowadays speak of such a great-scale religious and moral crisis of the Polish Institutional Church, seems to be more of a hypothetical problem and a research question than a real fact.

\section{Short final reflection}

The apt statement just given of Fr. W. Piwowarski, a distinguished researcher knowledgeable about the institutional Church and its political aspirations, seems to find vindication in the contemporary sociological description of the Church in Poland - its religious and secular role, its fears and phobias, and its confusions, which have been sketchily presented in the present paper. The results of multiple research projects, including those referenced and discussed in the present context, as well as the observations of theologians, attests to its accuracy and adequacy. This conclusion might also be seen as a fundamental answer to the general question stated at the outset of the present paper: what is the perception and evaluation of the institutional Church on the part of the present-day Polish Catholics when it comes to its religious-spiritual as well as secular dimension, present in non-religious roles and functions - including moral problems and dilemmas. The problems tackled and discussed in the present context demonstrate the diversity of attitudes expressed by Polish Catholics - both adults and the young - with respect to the institutional Church, as well as the range of their trust and lack thereof with respect to the Church as a whole, as well as when it comes to the particular structures and forms of wielding religious and secular power in society, including the interference of the hierarchy with the operation of state and local governments. Contemporary Polish Catholics, in their statistical majority, tend to question the model of an oppressive Church, which is afraid of the loss of dominance over the laity, and do not identify with the current forms of Church activity in state and society. They do also move away from the Church with increasing intensity and courage, attempting to find their own path to God that does not involve help on the part of the clergy. Their convictions, attitudes and evaluations of the drawbacks of the Church are congruent with the reflections and suggestions advanced by Fr. Rogowski and other theologians pointing to the Church having lost its way socially 
and morally. These Catholics do also point to the necessity of reforming and renewing the "old" model of the Church, with an intention to change their own role in its structures - from object to agent, from submissive to equal, in relations with the parish clergy (cf. Mariański, 2009, pp. 55-87).

In the current model of the Church, Polish Catholics perceive, themselves, the disregard for the communal dimension as well as the lack of will to foster dialogue with the faithful on the part of a large percentage of the clergy, which shows itself with respect to every vital matter associated with their religious and moral lives (cf. Potocki, 2008, pp. 25-42). In such a "renewed" Church, Catholics would like to find the roots of their religious faith, and to join in the building and development of their parish community. In such a spiritually and religiously reinvigorated Church, a place would have to be found for all those who have been excluded, for various reasons, from the Church and its religious and moral influence, so far as they demonstrate a will to rebuild and renew the bonds with the Church community. Such wishes are addressed to the Church by Polish Catholics, especially the young, in the hope that they are seen and listened to with seriousness, and that their expectations would be implemented in the modernised (updated) plans for religious and secular activity in the parish, as well as other conditions of individual and public life.

A sociologist of religion could ask the question whether the constantly confused institutional Church in Poland will listen to the voice of its members and of the people critical of it, and whether it will correctly read the message and properly evaluate its force and ideological import, and whether it will be willing to take it into consideration in its attempts to present religious and moral proposals compatible with the new times and new conditions of life? This question relates to the problem of the lay Catholics being at a loss, who cannot find their way in the confused institutional Church, and who in their great majority do not feel a parish bond, are not willing to cooperate in the creation of a common ecclesiastic good, and who, from what they see, conceive of the Church as consisting only of the Church authorities at various levels. The final and basic link of the Church are the lay members who are aware of their own objectification. The Church's being at a loss is contagious and affects the lay members. This question is bound to be of interest to future researchers of the Church in Poland - of its place and role on the scene of religious and typically secular meanings, within the frame of its functioning in the state and society. 


\section{Bibliography}

Baniak, J. (1997). Dynamika powołań kapłańskich i zakonnych w Kościele rzymskokatolickim w Polsce w latach 1900-1994. Studium socjograficzne. Kraków: Nomos.

Baniak, J. (2000). Katecheza szkolna w opiniach i ocenach młodzieży i rodziców. Poznańskie Studia Teologiczne, vol. 9, pp. 237-260.

Baniak, J. (2005). Zaangażowanie społeczne i polityczne Kościoła i księży w Polsce w wyobrażeniach katolików. Społeczeństwo i Kościół, vol. 2, pp. 107-154.

Baniak, J. (2007). Katolicy niewierzący i praktykujący? Między wiarą i ateizmem. Homo Dei, 1/282, pp. 23-43.

Baniak, J. (2010). Powołania kapłańskie i zakonne w Kościele katolickim w Polsce. In J. Baniak (red.), W poszukiwaniu sensu. O religii, moralności i społeczeństwie. Kraków: Nomos, pp. 307-315.

Baniak, J. (2010a). Kościół instytucjonalny w krytycznym spojrzeniu dzisiejszych katolików polskich. W: K. Rędziński (red.), Edukacja w społeczeństwie ponowoczesnym. Gliwice: Wyd. Gliwickiej Wyższej Szkoły Przedsiębiorczości, pp. 245-272.

Baniak, J. (2012). Powołania do kapłaństwa i do życia zakonnego w Polsce w latach 19002010. Studium socjologiczne. Poznań: WNS UAM.

Baniak, J. (2012a). Łapownictwo w moralnej ocenie religijnych i niereligijnych studentów stacjonarnych i niestacjonarnych. Folia Sociologica, 40, pp. 167-190.

Baniak, J. (2015). Religia katolicka i Kościół rzymskokatolicki w wyobrażeniach młodzieży polskiej. Od akceptacji do kontestacji. Kraków: Nomos.

Baniak, J. (2015a). Od akceptacji do kontestacji. Moralność katolicka w krytycznym ujęciu i ocenie młodzieży polskiej. Warszawa: Difin.

Borowik, I. (2005). Stosunek młodzieży do Kościoła rzymskokatolickiego w Polsce w perspektywie wywiadów biograficznych. Socjologia Religii, vol. 3, pp. 149-166.

Camara, H. (1995). Żyć Ewangeliq. Warszawa: Pax.

Gowin, J. (1995). Kościół po komunie. Kraków: Znak.

Grabowska, M. (2001). Religijność i Kościół w procesie transformacji w Polsce. In E. Wnuk-Lipiński, M. Ziółkowski (red.), Pierwsza dekada niepodległości. Próba socjologicznej syntezy. Warszawa: Instytut Studiów Politycznych PAN, pp. 128-142.

Kutyło, Ł. (2012). Kościół katolicki i religijność polskiego społeczeństwa po 1989 roku. Rozważania opierające się na założeniach paradygmatu ekonomicznego. W: J. Baniak (red.), Religia i Kościół w społeczeństwie demokratycznym i obywatelskim w Polsce. Między losem a wyborem. Poznań: Wyd. Naukowe WNS UAM, pp. 149-166.

Kwiatkowski, M. (2001). Kościół katolicki w Polsce a duch kapitalizmu. W: J. Baniak (red.), Katolicyzm polski na przełomie wieków. Mity, rzeczywistość, obawy, nadzieje. Poznań: WT UAM, pp. 107-120.

Leskovitz, J. (2013). Social Security Death Index. Boulder: CO.

Mariański, J. (1990). Moralność w procesie przemian. Szkice socjologiczne. Warszawa: IW Pax.

Mariański, J. (2005). Kościół katolicki w Polsce a życie społeczne. Studium socjologiczno-pastoralne. Lublin: Gaudium. 
Mariański, J. (2009). Kościół katolicki w świadomości i ocenach dzisiejszych Polaków. Społeczeństwo i Kościól, vol. 6, pp. 55-87.

Mariański, J. (2013). Kościół katolicki w Polsce w przestrzeni życia publicznego. Studium socjologiczne. Toruń: Wyd. Adam Marszałek.

Mazurkiewicz, M. (2001). Kościół i demokracja. Warszawa: UKSW.

Nublier, J. (1989). Église et le patrimoine, Paris.

Piwowarski, W. (1991). Kapłan - Kościół - duszpasterstwo. Ład. Katolicki Tygodnik Społeczny, 10, pp. 1-2.

Potocki, A. (2007). Wychowanie religijne w polskich przemianach. Studium socjologiczno-pastoralne. Warszawa: Wyd. Uniwersytetu Kardynała Stefana Wyszyńskiego.

Potocki, A. (2008). Podmiotowość laikatu w kontekście duszpasterskim. Społeczeństwo i Kościół, vol. 5, pp. 25-42.

Przybecki, A. (1986). Urzeczywistnianie się Kościoła w środowisku akademickim. Poznań: PWT.

Przybecki, A. (2009). Budować wspólnotę czy administrować? Pawłowa inspiracja dla polskiego duszpasterstwa. Teologia Praktyczna, vol. 10, pp. 77-85.

Ratzinger, J. (1997). Sól ziemi. Z kardynałem rozmawia Peter Seewald. Kraków: Znak.

Rogowski, R. (2001). Kościół zagubiony. In J. Baniak (red.), Katolicyzm polski na przełomie wieków. Mity, rzeczywistość, obawy, nadzieje. Poznań: WT UAM, pp. 89-106.

Sroczyńska, M. (2002). Obraz Kościoła i jego miejsce w życiu społeczno-politycznym. In W. Zdaniewicz, T. Zembrzuski (red.), Postawy społeczno-religijne mieszkańców archidiecezji łódzkiej, Łódź: Wyd. Archidiecezjalne, pp. 107-118.

Tischner, J. (1999). Ksiq̨dz na manowcach. Kraków: Znak.

Zaręba, S.H. (2008). W kierunku jakiej religijności? Studia nad katolicyzmem polskiej młodzieży. Warszawa: Zakład Wydawnictw Statystycznych. 
